\title{
Diacronie
}

Studi di Storia Contemporanea

$N^{\circ} 10,2$ | 2012

Digital History: la storia nell'era dell'accesso

\section{Digitizing the Seminar Paper}

A graduate student perspective on how digital tools shape scholarship

\section{Brian Sarnacki}

\section{(2) OpenEdition \\ Journals}

\section{Electronic version}

URL: http://journals.openedition.org/diacronie/2802

DOI: 10.4000/diacronie.2802

ISSN: 2038-0925

Publisher

Association culturelle Diacronie

\section{Electronic reference}

Brian Sarnacki, « Digitizing the Seminar Paper », Diacronie [Online], № 10, 2 | 2012, document 3, Online since 29 June 2012, connection on 02 May 2019. URL : http://journals.openedition.org/diacronie/2802 ; DOI : 10.4000/diacronie.2802 


\section{Diacronie}

\section{3/}

\section{Digitizing the Seminar Paper}

\section{A graduate student perspective on how digital tools shape scholarship}

Brian SARNACKI *

In the early twentieth century, Grand Rapids, Michigan addressed a major political scandal, which was the tipping point of municipal politics in Grand Rapids between politics rooted in personal connections and those centered on business-like administration. However, reform moved slowly, hindered by the social and spatial relationships of the elite. Using digital tools in a digital history seminar shaped my analysis of these personal and spatial relations. As a vital step in my research process, the construction of a digital project not only informed my written argument, but also fundamentally shaped it. It also reveals the importance of small scale digital research projects, made accessible through the use of open access tools, in the ultimate widespread adoption of the digital humanities. 


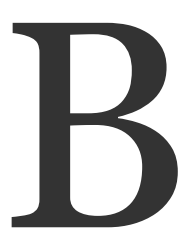

oth historically and currently, large research projects have dominate the field, from the Google N-Gram project and "Culturomics" to Hypercities to the Spatial History Project to the Valley of the Shadow ${ }^{1}$. These massive undertakings require time, collaboration, funding, research assistants, and, in most cases, tenure. These large scale projects also produce cutting edge scholarship, provide training to students like myself and make scholarly research open and accessible. The increasing use the digital medium to conduct, display, and disseminate their research has forced humanists to rethink the traditional structures of academia, including tenure and promotion, peer review, and publishing. Scholars cannot simply transpose academic structures onto digital scholarship. They need to reshape the old structures in a sustainable way for the future production of knowledge. While big data produces big results, not every scholar has the support, time, or opportunity to engage in digital projects that require, at the very least, as much effort as an extensive monograph. Scholarship is not kept solely in books, but also journal articles (and numerous other things for that matter). The Roy Rosenzweig Center for History and New Media's PressForward, a platform for collecting, review, and publishing online scholarship and the American Historical Review's call for submissions for its prize for best digital article are a few of the academy's recognition that the digital humanities need to support smaller scale research projects ${ }^{2}$. Though excited by the future opportunities and encouraged by scholars' efforts to rethink the long standing structures of academia, I want to push the discussion even further. To truly make the digital humanities mainstream, the "digital" identifier must become redundant. The

The author would like to thank you all those who have provided support during his research on the water scandal. In particular the department of history at the University of NebraskaLincoln, Timothy R. Mahoney, who has advised his research on the Grand Rapids water scandal and Douglas Seefeldt, instructor of History 970 who has mentored him on the digital humanities, his classmates in History 970 and other graduate students that the University of Nebraska-Lincoln who have helped him work through various issues about digital history, and the commenters, presenters and audience members at the Eighth Annual Loyola University Chicago History Graduate Student Conference and HASTAC V at which the author presented materials pertaining to his digital project and research.

${ }^{1}$ The Google N-Gram project can be found at URL: < http://books.google.com/ngrams > [accessed 14 may 2012]; MICHEL, Jean-Baptiste et al. «Quantitative Analysis of Culture Using Millions of Digitized Books», in Science 331, 14 January 2011, URL: < http://www.sciencemag.org/content/early/2010/12/15/science.1199644 > [accessed 14 may 2012]. The Spatial History Project can be found at URL: < http://www.stanford.edu/group/spatialhistory/cgi-bin/site/index.php > [accessed 14 may 2012]. The Valley of the Shadow can be found at URL: < http://valley.lib.virginia.edu/ > [accessed 14 may 2012].

2 PressForward can be found at URL: < http://pressforward.org/ > [accessed 14 may 2012]. The American Historical Review's call for submissions can be found at URL: < http://www.indiana.edu/ ahrweb/Digital_Article_Prize.pdf > [accessed 14 may 2012]. 
reevaluation of peer review, publishing, and tenure are all vital steps in reshaping the humanities in a way that can fully integrate digital scholarship. I would like to submit another, less discussed, step in incorporating the digital humanities, the graduate research seminar. Using my experiences from the University of Nebraska-Lincoln's History 970: Digital History Seminar3, I argue humanists will not complete the socalled "digital revolution" or "computational turn" until it enters the classroom, where future faculty perfect their trade. Universities need to rethink the research seminar and the seminar paper for digital scholarship to impact the humanities, not just the digital humanities.

Central to any effort of rethinking the graduate research seminar is making the digital medium approachable and manageable. The number of students in History 970, thirteen in the semester I took the course, clearly reflected an interest in learning about the digital humanities, especially because I do not believe most of the students would have identified themselves as digital humanists before the course began(or even after in many cases). Having previous experience in digital history coursework and some basic knowledge of HTML and CSS, I began the course as one of the more advanced students. Even given this advantage, the semester time limit was daunting. Unlike the traditional research seminar, in which graduate students conduct original primary and secondary research, our professor, Douglas Seefeldt, encouraged us to utilize research already collected. The digital history research seminar taught new methodologies of analyzing and presenting research. Learning the craft of history through reading and writing is important for any graduate student. However, traditional research seminars also provide a certain level of comfort for students, as the course requires the same skills as virtually any other history class. In taking the digital research seminar, students, especially the non-digital humanists, pushed their intellectual boundaries. The digital history seminar forced students to conceptualize their research differently. The hypertextual, visual, and public nature of the Internet brought new practical and theoretical challenges that, in my experience, informed my traditional scholarship. Just as a graduate student may build on a seminar paper in a thesis or dissertation, my digital project became a vital part of the way in which I approached my rather traditional looking Master's thesis 4 . Making scholarship for the digital medium during

\footnotetext{
3 My project can be found at URL:

< http://segonku.unl.edu/student_projects/hist970/s11/bsarnacki/ > [accessed 14 may 2012] or URL: < http://www.briansarnacki.com/projects/the_corrupt_network/ >[accessed 14 may 2012] and projects from other students in History 970 can be found at URL : < http://segonku.unl.edu/student_projects/hist970/s11/ > [accessed 14 may 2012]. 4 Brian Sarnacki, A Small City's Big Scandal: Municipal Corruption, Progressive Reform, and the Grand Rapids, Michigan Water Scandal, 1900-1906, MA thesis, University of Nebraska-
} 
the formative stages of my writing, the digital history seminar bridged the gap between my digital and non-digital work, rendering any differentiation between the two types of scholarship ultimately artificial.

Given the short time frame of approximately four months, in which to construct an original digital history project, the digital project created in a seminar looks more like a traditional seminar research paper than a large scale projects completed over several years. During a traditional research seminar, I would spend much of the early part of the project reading secondary literature and collecting primary sources that I would then use to write a article-length paper. In the digital research seminar, I spent almost all of the semester working on the "writing" portion of the project. However, "writing" in this sense covers more work than organizing words. To "write" my digital project, I needed to build an outline of the different sections, create the webpages, and fill them with both textual and visual content. In hopes of optimizing the hypertextuality of my work, I created various ways in which to view my content including chronological, thematic, and historiographical narratives, individual visualizations, and archival materials. Though the organizational, coding, and narrative portions of my project were all important parts of the larger process, in this essay I will focus on my creation of dynamic visualizations. Using freely available online tools, I was able to create different, interactive ways to display my data. These tools allowed my project to tap into the promise possibilities electronic medium while shaping my approach to my own research.

In order to discuss my use of digital tools, however, I must first give some background on my research. My Master's thesis examines a political scandal in Grand Rapids, Michigan at the dawn of the twentieth century within the context of Progressivism and municipal reform in the United States. The water scandal, as the few historians of Grand Rapids have referred to it, was a fairly typical instance of municipal corruption. Politicians abused their power by receiving bribes in exchange for awarding a pair of New York conmen a public works contract for the building of a pipeline that would pump fresh water into the city. The importance of Grand Rapids and its water scandal, one of many scandalous events in the city's history, lies in Grand Rapids' position as a small city. A regionally influential urban center located between Detroit and Chicago, Grand Rapids filled a niche position in the national economy as a leading furniture manufacturer. However, historians have largely overlooked the path of small cities like Grand Rapids to Progressivism in favor of the national narrative of

Lincoln, 2011, URL: < http://digitalcommons.unl.edu/historydiss/42/ > [accessed 14 may 2012]. 
Progressivism, concentrating on grassroots reformers and strong ideological leaders. On the other hand, the water scandal demonstrates small city Progressivism was a product of city leaders gradually adopting and applying Progressive ideas in a piecemeal fashion. In short, they used Progressivism to their advantage.

While historians after Peter Filene's "Obituary for the 'Progressive Movement" have exposed many of the inconsistencies, contradictions, and divisions within Progressive movements, for the most part, scholars have not radically altered the conception of Progressives as primarily reformers. Historians have humanized Progressives, grounding reformers in their time and place, helping to explain the racial, gender, and anti-democratic stances many reformers supported, but the conception of heroic reformers remains. Historians have simply added a heroic flaw. Charles and Mary Beard found Progressives to be part of the "spirit of reform". Richard Hofstadter framed the narrative of The Age of Reform around a period of reform set apart from the rest of American history. Even after Peter Filene attempted to deconstruct the Progressive Movement, scholars did not completely abandon the heroic rhetoric. Robert D. Johnston has a sympathetic view of "radical" middle class Progressives in Portland, Oregon, painting them as passionately democratic. Michael McGerr's $A$ Fierce Discontent argues radical middle class Victorians fought to remake society into a middle class utopia, a flawed but valiant goal that McGerr claims has affected modern politics. McGerr argues "the epic of reform" during the Progressive Era has made "the less-than-epic politics" of the nation one hundred years later. This focus on reformers as the vehicle for the Progressive Era reforms produces narratives with a focus on big cities and the leading men and women of the period5.

In beginning my research on the water scandal, I found the bipartisanship nature of the corruption was striking as seven Democratic and seven Republican aldermen were indicted during the life of the scandal in addition to other prominent local politicians such as the Democratic mayor and a Republican state senator. As I dug into the city's history, the intertwined nature of the city's elite, some of whom were involved in the corruption scheme, also became increasingly important. In History 970, I made it my goal to use the digital medium to explore the social, political, economic, and spatial

\footnotetext{
5 FILENE, Peter, "An Obituary for 'The Progressive Movement'», in American Quarterly, 22, 1/1970, pp. 20-34. BEARD, Charles Austin, BEARD, Mary Ritter, History of the United States New York, Macmillan Co., 1921, p. 538; HOFSTADTER, Richard, The Age of Reform: From Bryan to F.D.R., New York, Vintage Books, 1955; JOHNSTON, Robert D., The Radical Middle Class: Populist Democracy and the Question of Capitalism in the Progressive Era Portland, Oregon, Princeton, Princeton University Press, 2003; McGERR, Michael, A Fierce Discontent: The Rise and Fall of the Progressive Movement in America, 1870-1920,New York, Oxford University Press, 2003, p. xiv.
} 
relationships of some of the elite and political figures involved in the scandal. The effectiveness of the tools I used and the analysis that stemmed from them eventually made the connected nature of the elite a central facet of my argument. My thesis argues the connected nature of the elite initially stymied reform and prevented widespread criminal accountability. However, the water scandal also marked a crucial role in the emergence of Progressive reform because the city made a genuine, though often politically charged, effort to confront issues of corruption and reform.

In selecting what visualization to start with, I began on more familiar ground. During my digital history coursework, I had been exposed to the program Exhibit, an organizational and mapping tool originally developed at the Massachusetts Institute of Technology as part of the SIMILE (Semantic Interoperability of Metadata and Information in unLike Environments) project ${ }^{6}$. Though I had various ideas pertaining to the comprehensiveness of my data set, I eventually settled on restricting my visualization to the aldermen during the beginnings of the water scandal. I focused on the aldermen because their handling of the earliest bribery accusations created much of the initial public outcry that would drive the water scandal. One of the initial turning points of the water scandal, city attorney Lant Salsbury was arrested in Chicago for allegedly stealing money of an Omaha investor who hoped to used Salsbury's connections to bribe the Grand Rapids city council to award him the city's contract for a new water supply. With rumors of the corrupt scheme swirling about the city just a few months before city elections, Republican aldermen seized on the opportunity to run an anti-corruption campaign. Twelve of the twenty-four were up for election each year and they successfully gained control of the city's common council by winning two extra seats running against the corruption of the democratic Salsbury. Republicans claimed they were «worthy of the confidence and respect of the people»7 and would create «safeguards against corruption in city affairs» ${ }^{8}$, if they gained control of the council. Though the Republicans wrestled control of the common council, the political power was still split fairly even. Following the 1901 election ran specifically against Salsbury, the common council held an election for the city's attorney. However, in two separate secret ballot elections Salsbury won enough Republican votes (at least one the first vote and at least three the following) to gain reelection in spite of his legal woes. Even in a final public re-vote, Salsbury still won reelection twelve to eleven. Thirteen of the aldermen in office at the time of these votes would be implicated in the water scandal

\footnotetext{
${ }^{6}$ URL: < http://www.simile-widgets.org/ > [accessed 14 may 2012].

7 Grand Rapids Herald, 30 March 1901, p. 7.

${ }^{8}$ Ibidem.
} 
over the next several years, most by Salsbury himself. In this light, his reelection may not seem surprising. However, the voting patterns conform to political lines moreso than corruption. Four Republican aldermen who would be implicated for taking bribes from Salsbury voted against him and five Democrats untouched by the scandal still voted in favor of their Democratic comrade. Despite bipartisan corruption, the attempts to handle corruption became, for the most part, a partisan issue 9 . My visualization of these aldermen and their voting patterns was an attempt to understand some of this focus on corruption as a party line issue rather than an ethical concern over "good government". I created the visualizations so that the user could select the data points mapped by the alderman's political party, years served, vote on Salsbury's reelection, legal implication in the scandal, and if they were acquitted. Spatializing the aldermen's political votes in particular brought me to the realization that physical space and personal relationships may play an important role in municipal governments. Though I had to approximate some of the aldermen's addresses due to the physical changes of the city over the last hundred years, the fifth ward's aldermen still best portrayed the realities of city politics that could facilitate corruption underneath public political debates. The aldermen, John Donovan and Adrian Schriver, lived at twenty-nine and thirty two Page street respectively ${ }^{10}$. Coming from different political parties it is more than feasible that their status as neighbors could have aided their participation in the water scandal's bribery scheme, for which they both had to pay fines. Beginning with this visualization, the consideration of personal and spatial relationships became an increasingly central part of my thesis' argument.

The other tools I used came from a freely available JavaScript suite of visualization tools, called the JavaScript InfoVis Toolkit ${ }^{11}$. I utilized their ForceDirected visualization to depict some of the intertwined nature of the city's elite and their SpaceTree visualization to highlight the importance of Lant Salsbury as the central figure in the bribery scheme. My ForceDirected visualization displayed connections between objects and allows users to manipulate the results to better explore these connections. I took a small slice of the Grand Rapids elite to emphasize the social relationships that facilitated and crossed political alliances. I was able to communicate some information about each point through the color (red figures stood for Republican affiliated people,

9 Grand Rapids Herald, 7 May 1901, pp. 1, 3-4; Grand Rapids Herald, 16 June 1901, p. 1; Grand Rapids Herald, 18 June 1901, p. 1; Grand Rapids Herald, 19 June 1901, p. 3; Grand Rapids Herald, 25 June 1901, p. 1; LYDENS, Z. Z., The Story of Grand Rapids, Grand Rapids, Kregel Publications, 1966; GOSS, Dwight, History of Grand Rapids and its Industries, 2 voll., Chicago, C.F. Cooper, 1906.

${ }^{10}$ Grand Rapids City Directories, 1900, 1902.

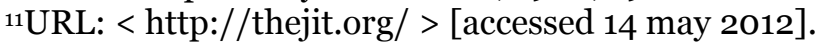


blue figures for Democratic affiliated people and green figures stood for neutral or politically ambiguous people and institutions), shape (stars represented people, squares represented businesses, and circles represented social organizations), and names. This digital tool allowed me to display the analytical process of drawing connections between people and organizations that I had already been doing on scraps of paper and dry erase boards. I was pleased I could help the user experience the formation of my argument in addition to my narration of my findings, one of the advantages interactive digital scholarship can make.

The connections displayed in the ForceDirected visualization specifically helped inform my analysis of the city's elite's involvement including its mayor George Perry. Though a seemingly Progressive candidate and mayor, Perry clearly indulged in Gilded Age style personal politics, which may have culminated with his participation in the water scandal's bribery scheme. Perhaps the clearest example of Perry's use of his mayoral powers for his personal gain, was the city's coal contract, half of which went to the Century Fuel Company. In June 1901, well into the beginnings of the water scandal, the Common Council's committee on buildings, comprised of three Democrats all of whom would be fined for bribery during the water scandal, Clark Slocum, Daniel Lozier, and Charles Johnson awarded the lucrative deal to the Century Fuel Company, whose stockholders included George Perry, Dudley Waters, Perry's appointee to the Board of Public Works, William Hayden, a close Perry ally and employer of Alderman Johnson and Charles A. 


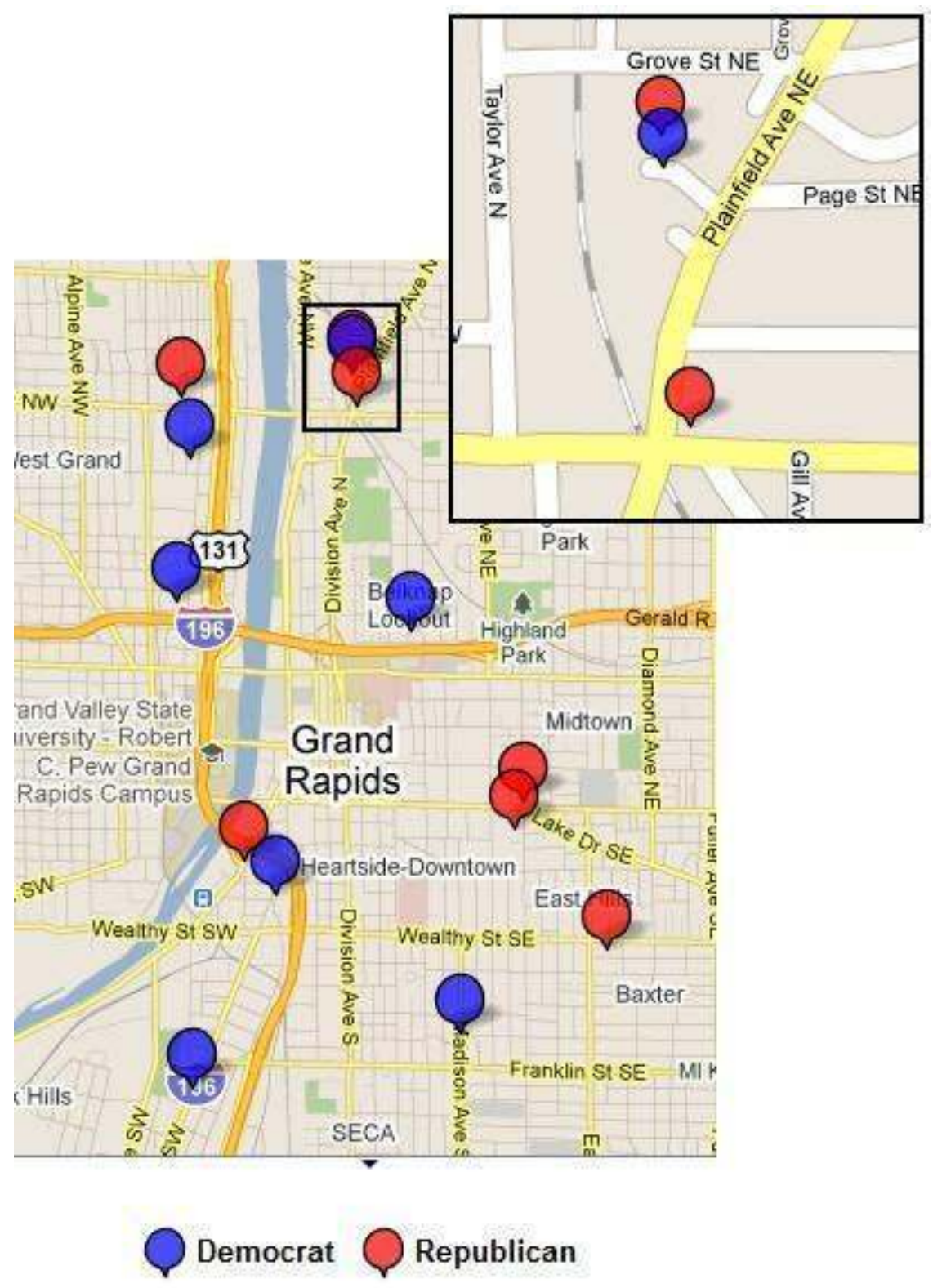

Figure 1.

Screenshot of my Exhibit visualization showing the aldermen drawn into the water scandal, with Aldermen Donovan and Schriver highlighted.

Phelps, the President of the company and another Perry appointee who served as a police commissioner ${ }^{12}$. Despite the claims of openness in his political speeches, Perry clearly engaged in backroom dealings that benefited himself and his political allies. This seeming contradiction of values demonstrates the incomplete acceptance of Progressive ideals pertaining to municipal government. Perry could simultaneous

${ }_{12}$ Grand Rapids Herald, 25 June 1901, p. 4. 
present himself as a Progressive mayor and engage in actions that violated the managerial principles of good government.

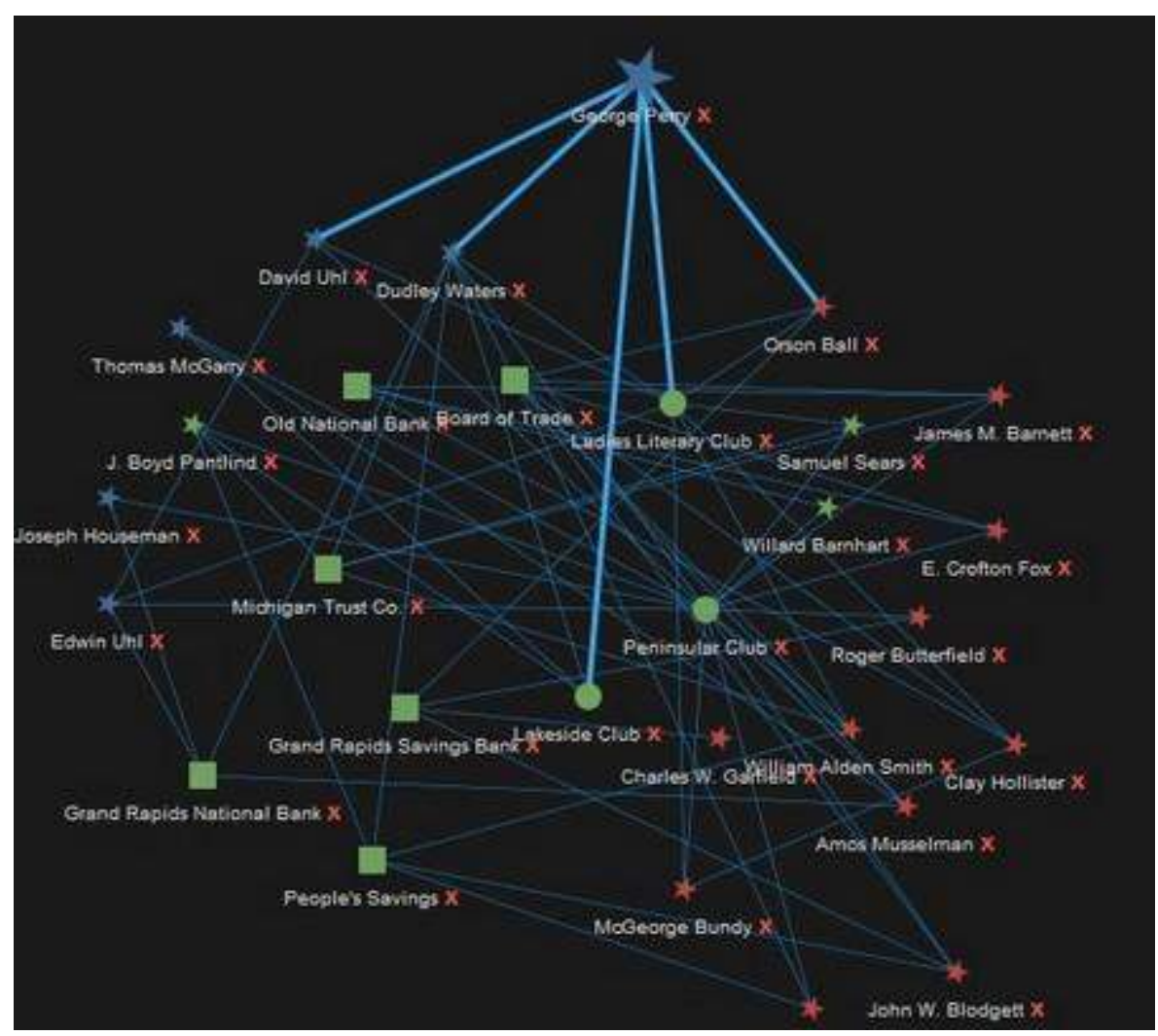

Figure 2.

Screenshot of my ForceDirected visualization depicting some of the social, political, and economic connections of the Grand Rapids elite, with mayor George Perry highlighted.

My SpaceTree visualization was a rather simple depiction of the flow of money in the main bribery scheme uncovered by the water scandal. I chose this tool because it displayed Salsbury's centrality in the corruption in a rather striking way. While the money flowed through its first few handlers one individual at a time, when the cash reached Salsbury, it suddenly began moving in all sorts of directions. Salsbury allegedly distributed bribes to twenty-five different politicians. In the my Master's thesis I continued to expand the role of Salsbury, who served the longest prison sentence and acted as the state's star witness. In the local histories and narratives following the scandal, Salsbury became the figure associated with the water scandal, despite widespread participation. 


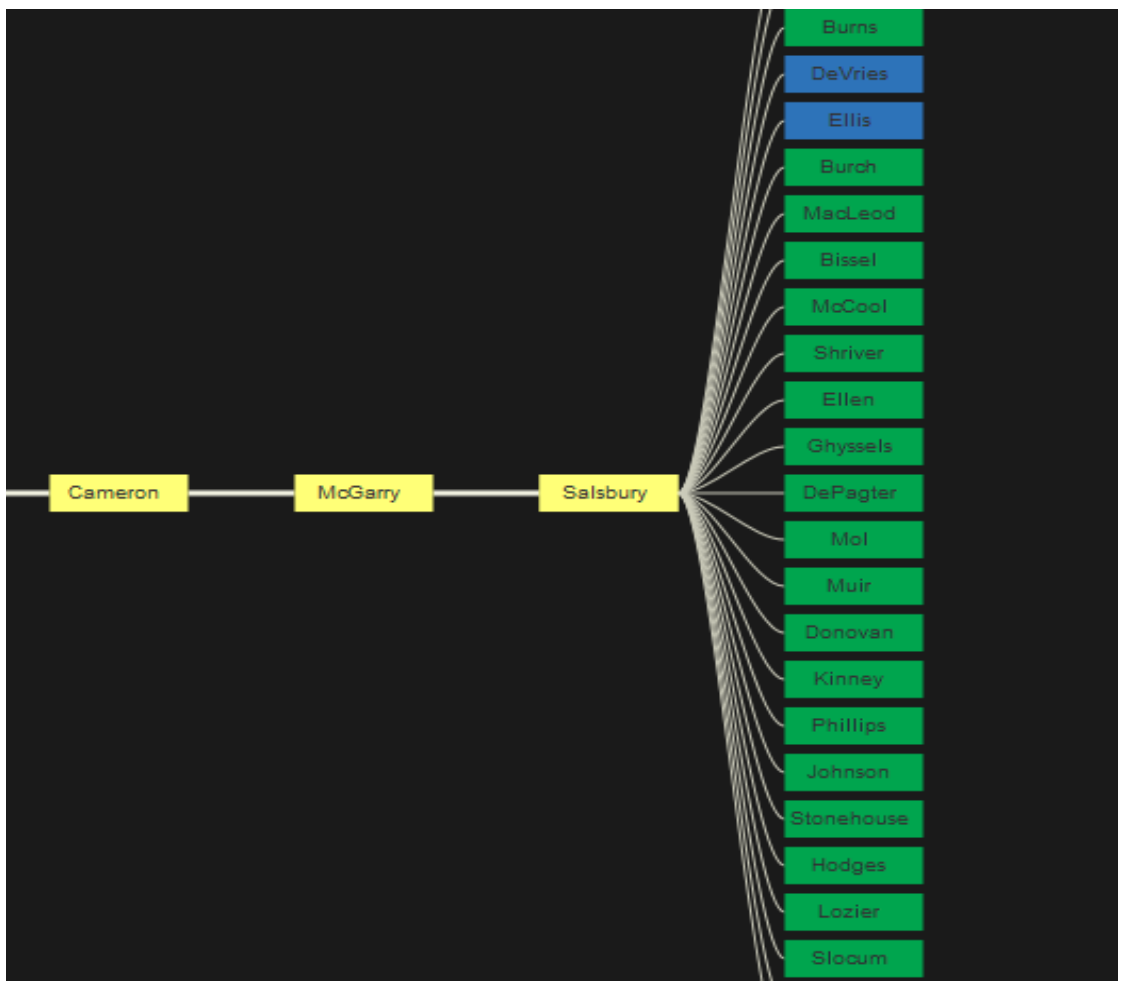

Figure 3.

Screenshot of my SpaceTree visualization showing the importance of Lant Salsbury in the spread of corruption throughout Grand Rapids' municipal politics.

Shortly after the water scandal in 1906, Dwight Goss described Salsbury as "a young successful attorney with a penchant for politics" Though Salsbury was "ambitious for wealth and position, he was not, to those who knew him well, considered overscrupulous in means and methods for achieving success." He was also «personally popular and easily made friends» and "thoroughly understood men, their motives, their dispositions, their characters and their weaknesses» ${ }^{13}$. Writing sixty years later, city historian Z.Z. Lydens called Salsbury the scandal's "arch villain” describing Salsbury as «a country boy», who "was the embodiment of the epigram, 'Too clever is dumb'». As «the typical city slicker of the melodrama, a diviner of human nature with a knack for exploiting it», Salsbury «was personally popular and persuasive, though not generally deemed pure in heart»14. In writing about the water scandal city historians have pointed the finger at Salsbury as the main actor, but have also tried to understand and perhaps even rationalize his reasons for participating in the bribery scheme, depicting Salsbury not necessarily an evil mastermind, but a flawed person of the times. This memory of Salsbury as the central figure is in part true, though it may lend greater

${ }^{13}$ GOSS, Dwight, op. cit., pp. 1021-1022.

14 LYDENS, Z. Z., op. cit., p. 58. 
insight into the way in which the city viewed the corruption scandal. The leaders of Grand Rapids recognized the importance of locals taking some responsibility for its municipal graft. However, most of that responsibility fell on Lant Salsbury. In essence, Grand Rapids only accepted partial responsibility for its politicians' corruption by placing the blame on the shoulders of a single man.

Each of the visualizations I constructed deeply influenced the analysis and argument presented in my Master's thesis. Most importantly, I continued expanding upon my examination of the spatial and personal relationships of the city's elite in order to gauge the effectiveness of reform. I found that the Grand Rapids water scandal reveals the manner in which many smaller cities moved from municipal governments centered on personal relations and social connections, to a more Progressive government led by professional managers and their administrations. No political machine was dismantled and no dominant family displaced. The city's elite, though intimately involved in the scandal, remained largely in place. The Grand Rapids elite oversaw the gradual adoption of Progressive ideas and the water scandal was the vital first step in the city's implementation of an ethical system that informed the role of good government and the meaning of corruption.

Looking at my experience in History 970, it is clear the course accomplished all the normal objectives of any research seminar. I produced scholarship based upon primary and secondary research that expanded my analytical framework, refined my research, and produced a strong foundation for a future project, in this case a Master's thesis. However, my experiences also touched upon many of the promises of digital history and the digital humanities. The process was collaborative. Several students utilized Exhibit and we all helped each other figure out how to adapt the tool to our own needs. It was extremely interdisciplinary in that a friend outside of academia pointed me towards the visualization tools in the JavaScript InfoVis Toolkit. It produced a product of rigorous scholarship open to anyone with Internet access complete with customizable and dynamic visualization. History 970 was both traditional and cutting edge. It taught skills of critical thinking, analysis, and synthesis like any history course, while including digital skills both technical, like HTML and CSS, and theoretical, like multilinear narratives and interactive tools. For the digital humanities to become an integral part of academia, and not simply a niche field practiced by a handful of scholars, the digital humanities must become simply a normal part of practicing humanistic research. Courses like the digital research seminar will greatly aid in the full integration of digital scholarship. The digital tools I used to explore my research deeply 
influenced the arguments I made in subsequent work, even though that works was not digital in its presentation.

For others to practice digital research, digital tools must be made available. Many digital humanities centers like George Mason's Roy Rosenzweig Center for History and New Media, the University of Virgina's Scholar's Lab and the University of NebraskaLincoln's Center for Digital Research in the Humanities have produced easy to use open access tools for humanists. These centers and their products are essential to the widespread adoption of the digital humanities. As Stephen Ramsay points out, at the core of the digital humanities is building ${ }^{15}$. The digital humanities is not simply a theoretical approach, but a fundamental change in the way in which scholars approach, analyze, and disseminate answers to humanistic questions. In order for scholars to fully understand, and ultimately appreciate, the digital humanities, they must experience the digital medium, its promises, and its restrictions. Because every scholar cannot be expected to learn to code, the widespread availability of digital tools facilitates the adaptation of digital methodologies and the digital medium in scholars unfamiliar or new to the digital humanities. As I noted in the beginning of this essay, most of my classmates in History 970 would not have identified as digital humanists in the beginning of the course, but everyone produced original digital research projects. Tools, like those I used to create my visualizations, are vital for the involvement of scholars at differing ranges of technical expertise to create digital scholarship. Likewise, though I am fortunate to be at a university with a digital humanities center and a community of digital humanists, many are not. With the proliferation of online tools, scholars located away from the leading centers of innovation can still participate in the development of digital scholarship.

Though vital to the future of the digital humanities, open access digital tools are not perfect. Digital projects already face numerous issues surrounding sustainability, but when the creation of tools is outsourced, the author cedes even more control over the future of his or her project. I used Exhibit to create one of my visualizations and Exhibit relies on Google Maps for its mapping of data points. However, every change Google makes to its product threatens the long term sustainability of my project. For instance, the version of Google Maps that followed my project altered the way it used its Application Programming Interface (API) key, which crippled my Exhibit visualization. Without a new key, my visualization of the Grand Rapids aldermen is inaccessible. The preservation of parts of my project rely on Google, a for-profit company with much

15 RAMSAY, Stephen, «On Building», URL:< http://lenz.unl.edu/papers/2011/o1/11/on-building.html > [accessed 14 may 2012]. 
larger concerns, to continually maintain the small part of their company upon which Exhibit relies. These sustainability issues often seem terrifying to scholars better acquainted with the comforts of printed materials. While the risks can be moderated by the use of open access materials, which do not rely on any external companies, the benefits digital tools bring must ultimately comfort the scholar.

In order for the digital humanities to become a fully accepted part of the academic infrastructure, the digital humanities must move beyond large projects built out of social science-type labs. Individual scholars with small budgets, limited time, and little programming experience, like graduate students and humanists at small institutions, must be able to build their own digital work. Open access digital tools provide the greatest opportunity for digital scholarship to become widely available. As I found out in History 970, digital tools facilitate a relatively smooth translation of historical research into the digital medium. As I found out after History 970, digital scholarship can inform traditional, non-digital research just as much as scholarship in any other format. 


\section{* The author}

Brian Sarnacki is a Ph.D. student at the University of Nebraska-Lincoln where he obtained his M.A. in August 2011. He received his B.A. in history from the University of Notre Dame du Lac in May 2009.

URL: < http://studistorici.com/progett/autori/\#Sarnacki >

\section{Per citare questo articolo:}

SARNACKI, Brian, "Digitizing the Seminar Paper. A graduate student perspective on how digital tools shape scholarship», Diacronie. Studi di Storia Contemporanea: Digital History: la storia nell'era dell'accesso, 29/6/2012, URL:< http://www.studistorici.com/2012/06/29/sarnacki_numero_10/ >

Diacronie Studi di Storia Contemporanea $\beta$ www.diacronie.it

Risorsa digitale indipendente a carattere storiografico. Uscita trimestrale. redazione.diacronie@hotmail.it

Comitato di redazione: Marco Abram - Giampaolo Amodei - Jacopo Bassi - Luca Bufarale - Alessandro Cattunar - Alice De Rensis Barbara Galimberti - Deborah Paci - Fausto Pietrancosta - Matteo Tomasoni - Luca Zuccolo

Diritti: gli articoli di Diacronie. Studi di Storia Contemporanea sono pubblicati sotto licenza Creative Commons 2.5 Possono essere riprodotti a patto di non modificarne i contenuti e di non usarli per fini commerciali. La citazione di estratti è comunque sempre autorizzata, nei limiti previsti dalla legge. 